\title{
Opportunities of re-establishing underground mining in the borsod coal basin in north-eastern Hungary
}

\author{
József Molnár, Ákos Debreczeni, Richárd Tompa \\ Institution of Mining and Geotechnical Engineering, \\ University of Miskolc, Hungary
}

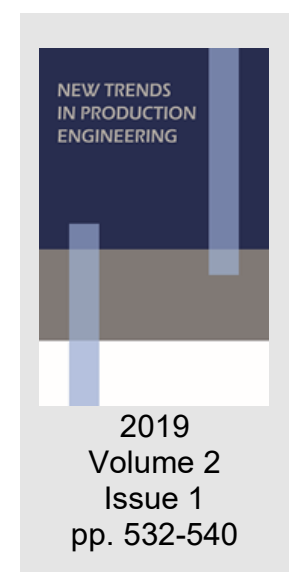

Date of submission to the Editor: 05/2019

Date of acceptance by the Editor: 08/2019

\section{CADASTRE OF HUNGARIAN COAL RESERVES}

Significant coal reserves remained in Hungary despite mine closures, and these could be taken into account when considering future fuel and raw material demand of the country. So Mining and Geological Survey of Hungary (MBFSZ) contributed a new cadastre of Hungarian coal deposits of greater or less reserves throughout the country which is available in electronic digital form (https://map.mbfsz.gov.hu/coal_cadastre/). Geological information that can be obtained using the database in question is of essential importance in mine design. Coal basins of Hungary are showed by Figure 1.

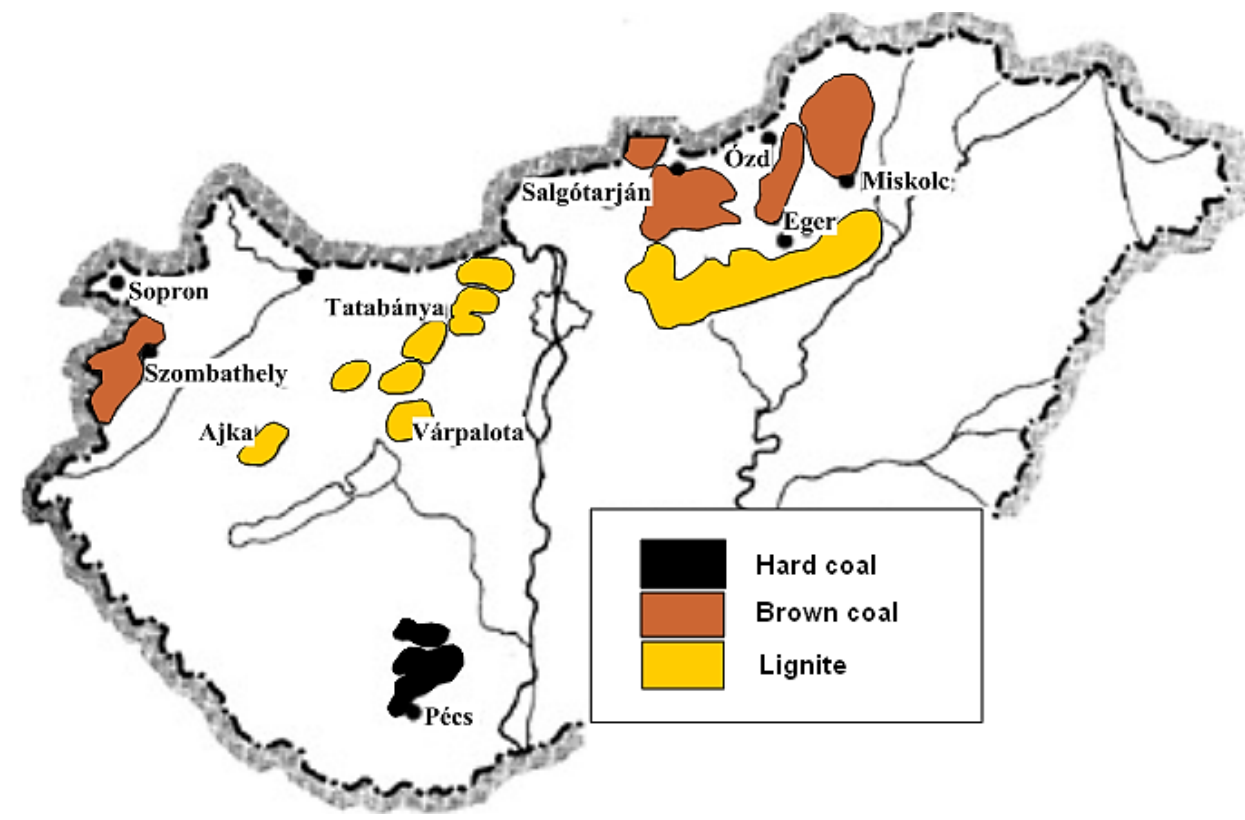

Fig. 1 Coal basins of Hungary

Source: Mining and Geological Survey of Hungary - MBFSZ

\section{DEMAND FOR NEW BROWN COAL SOURCES}

A special research took place in the past years analyzing possibility of establishing coal chemical industry in the Borsod region in question especially 
for methanol production. So reserves of brown coal were taken into consideration such as near Kazincbarcika (Tardona), Edelény (Szendrő), and Putnok (Dubicsány and Sajómercse II). Coal demand of chemical utilization should be considered a lucky situation from mining point of view. On the one hand such a plant needs coal of constant quantity and quality as raw material and on the other hand opening a new mine of economic output requires one or more major industrial consumers. Chemical industry which has similar remarkable traditions in the region as mining can be the only major buyer as utilization of coal for power generation is not preferred this time.

Although there are several brown coal deposits in the Borsod region, we focus on the Dubicsány and Sajómercse II ones (Figure 2). Both coal deposits are close the Sajó river at town of Putnok. Sajómercse II consists of the eastern remains of the former Putnok underground coal mine south of Sajó furthermore some 10 million tons of east of it. The Dubicsány deposit which is north of the river is totally untouched as no production operations were in it in the past.

Main properties of mining point of view of both deposits are described in the paper published by MBFSZ (Debreczeni et al. 2018). Institution of Mining and Geotechnical Engineering was participant in preparing mining plans.

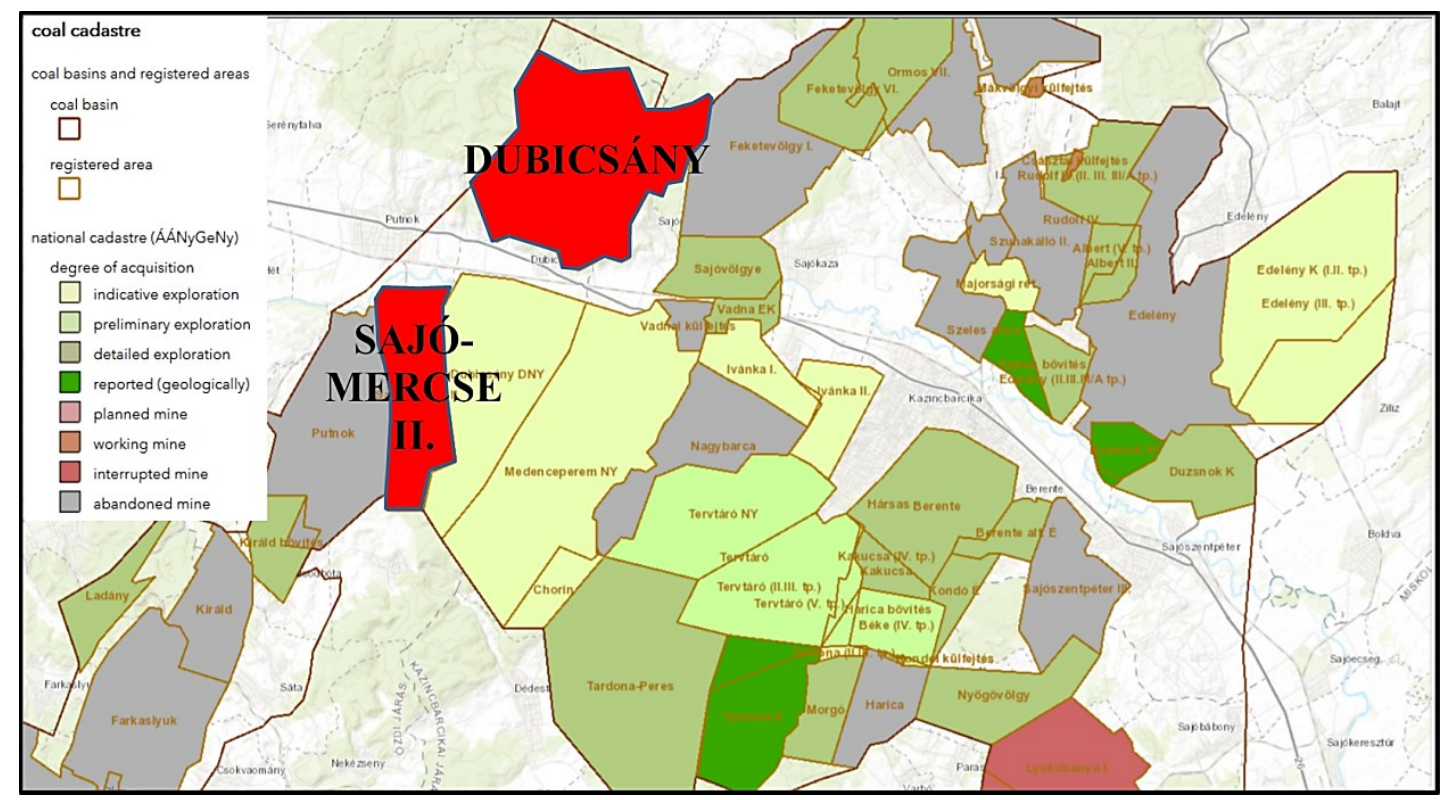

Fig. 2 Location of the Dubicsány and Sajómercse II coal deposits in the Borsod coal basin Source: Mining and Geological Survey of Hungary - MBFSZ

\section{The Dubicsány brown coal deposit}

262 boreholes were sunk on the $23.58 \mathrm{~km}^{2}$ area of the Dubicsány brown coal deposit. Both core sampling and geophysical analysis were done for the vast majority of the holes. Two coal seams (IV and V) are available. Seam IV is thin, not mineable and can be found only on a small part of the deposit. Seam $V$ is mineable and can be found over the whole area.

Thickness and mean calorific value of Seam $\mathrm{V}$ was determined for all boreholes throughout the whole deposit. Valuating thickness and specific heat content enabled more accurate determination of the borders of the parts of the mine (as 
shown fields North I, North II, South I and South II on Figure 3). Steadier seam thickness and calorific value in a mine field is more advantageous from mining engineering point of view.

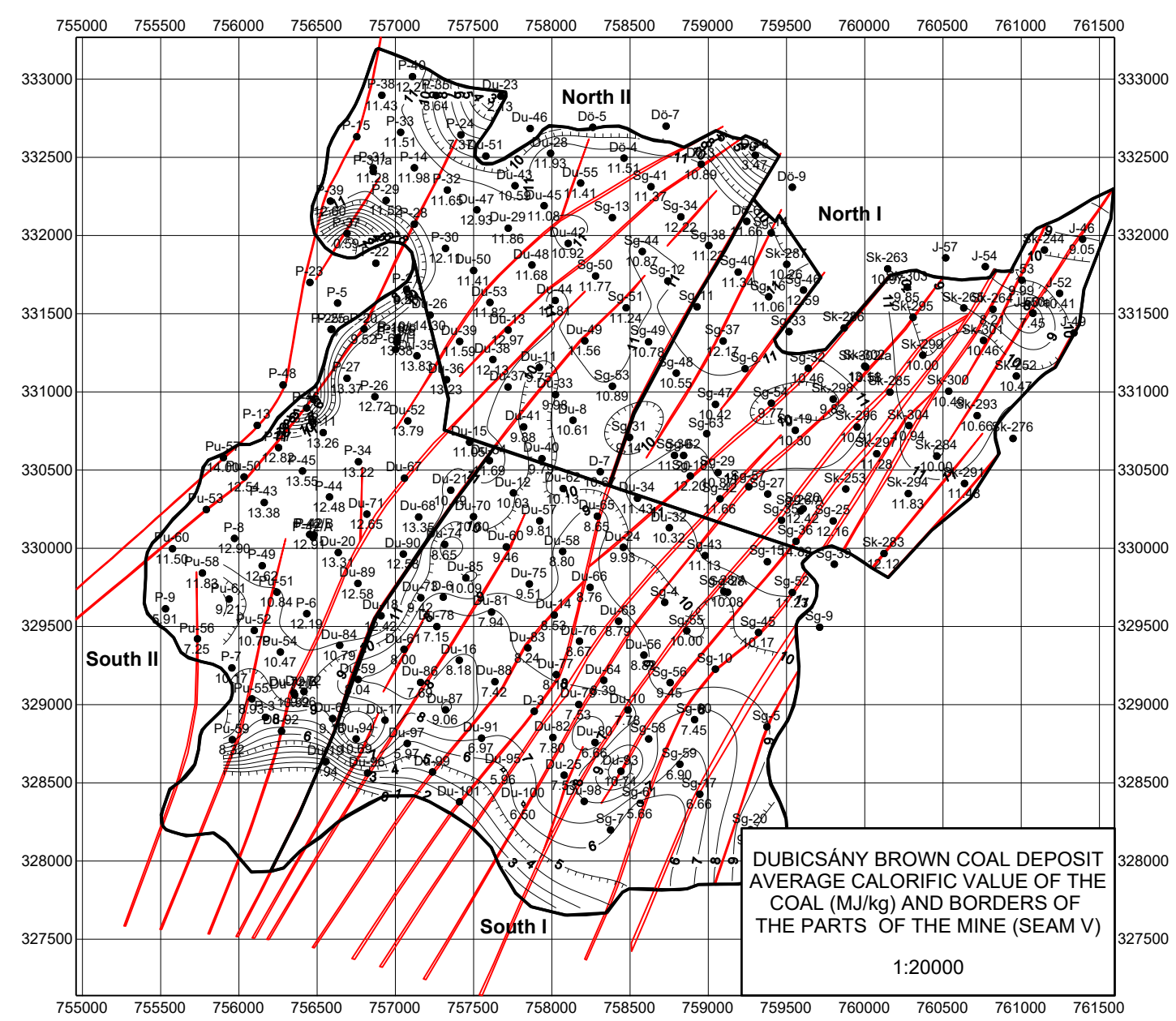

Fig. 3 Average calorific value of the coal $(\mathrm{MJ} / \mathrm{kg})$ and borders of the parts of the Dubicsány mine. Faults are highlighted by red lines

Source: Molnár (editor-in-chief), 2018

Total thickness of layers between the two seams (mostly sand) is of 70-72 $\mathrm{m}$ at average. Coal reserve of the Dubicsány deposit is concentrated in Seam V. Its thickness is 5-6 $\mathrm{m}$ on the vast majority of the deposit except on the southwestern part and near the border of the seam. Thinner parts can be observed only on the southwest area as the lower part of the seam is of rather poor quality. Upper part of the seam is of higher sulfur content furthermore of higher calorific value due to lower ash content. The lower layer of the seam is of lower sulfur content and calorific value, this latter one as a result of higher ash content. Lower calorific values can be observed for greater seam thickness.

According to recent technical standards and mining plans, upper part of the coal seam is worth mine out using underground methods. Height of the coal face in the longwalls is $2.5-3.5 \mathrm{~m}$, depth of the seam is $120-230 \mathrm{~m}$ on the northern and 200-300 $\mathrm{m}$ at the southern part of the deposit, thickness, mineable reserve estimates 49.9 million tons of $12.3 \mathrm{MJ} / \mathrm{kg}$ calorific value. The coal can be used as raw material for the chemical industry. Development of a new mine was 
planned by Borsod Coal Mines company, so two inclined shafts were sunk and more than $2000 \mathrm{~m}$ long drifts were made for exploration purposes beside drilling boreholes in the 1980ies. These old drifts should be replaced by new establishments.

The mine should be opened by two inclined shafts at the east side and a pair of main drifts from east to west as it was planned in the 1980ies. Later a new ventilation shaft or borehole will be necessary to enable proper ventilation. Planned output of the mine amounts 1.54 million tons per year. Mine construction takes 4.5 years. Output will be increased to the total output in 5 years plus time required by design and obtaining licenses. Mine is planned to operate 37 years at the annual 1.54 million tons output level. Number of employees is estimated 900 not including number of personnel of suppliers.

The main mine hazard to be expected is due to water contained in aggregates of the roof layers. Dewatering is planned by wells drilled from the surface and established in the hanging wall of the drifts. Quantity of water can be expected $12-14 \mathrm{~m}^{3} / \mathrm{min}$ during the mine construction and later $6-9 \mathrm{~m}^{3} / \mathrm{min}$. Water can be utilized in water supply of the region and/or industrial water in chemical industry utilizing coal. Mining operation does not risk drinking water reserves.

Environmental impact of an underground mine is much less than of a surface operation. Significant part of the inhabitants of the settlements of the region was employed by coal mining so favorable reception of a new mine can be expected.

\section{The Sajómercse II brown coal deposit}

The Sajómercse II deposit of $13.6 \mathrm{~km}^{2}$ area consist of the remaining eastern part of the former Putnok underground coal mine and the coal reserves east of it. Geological exploration was based both on boreholes, using core sampling and geophysical methods as well and summarizing experiences obtained in the Putnok Mine.

The coal bearing strata contain 6 seams (low and high Borsod strips, seams I, II, III and III/a). Total thickness of these strata estimates $110 \mathrm{~m}$, average depth is $270 \mathrm{~m}$. The coal strips do not belong to the industrial reserve. Similarly Seam III/a under Seam III does not worth for utilization too due to its low quality (8000 $\mathrm{kJ} / \mathrm{kg}$ calorific value) and irregular spread. Properties of the three main seams can be read in Table 1. The coal from these seams can be used as raw material for the chemical industry.

Table 1 Properties of coal seams of the Sajómercse II brown coal deposit

\begin{tabular}{|l|c|c|c|c|}
\hline & $\begin{array}{c}\text { seam } \\
\text { thickness } \\
{[\mathrm{m}]}\end{array}$ & $\begin{array}{c}\text { height of coal faces } \\
\text { of longwalls } \\
\text { [m] }\end{array}$ & $\begin{array}{c}\text { coal reserve } \\
\text { that can } \\
\text { be extracted } \\
\text { by longwalls } \\
\text { [million tons] }\end{array}$ & $\begin{array}{c}\text { average calorific } \\
\text { value of coal that } \\
\text { can be extracted } \\
\text { by longwalls [kJ/kg] }\end{array}$ \\
\hline Seam I & $0.8-2.45$ & $1.8-2.2$ (average: 2.00$)$ & 5.289 & 12650 \\
\hline Seam II & $0.7-5.65$ & $2-2.5$ (average: 2.25$)$ & 16.366 & 12000 \\
\hline Seam III & $0.8-6.2$ & $2.5-3.5$ (average: 3.00$)$ & 15.974 & 13500 \\
\hline total & & & 37.629 & 12728 \\
\hline
\end{tabular}


Uniaxial strength of Seams I and II is of 12-24 MPa. A little bit lower strength (8$18 \mathrm{MPa}$ ) can be observed in Seam III due to clay layers in it. Country rocks are mostly low strength water-bearing layers consisting mostly of sand and clay. Highest strength was observed in the covering rocks of Seam III which is favorable for main drifts. Water hazard furthermore mud intrusion should be expected in all seams from the hanging wall and the foot wall too. Dewatering plans must take it into account.

Development of the Sajómercse II coal mine and extraction of the coal reserve of Seam II are shown on Fig. 3. Development system consist of a pair of inclined shafts on the northern side of the seams, a pair of main drifts in seam III as its country rocks are of higher strength and finally a ventilation shaft or borehole on the south.

Planned output of the mine amounts 1.0 million tons per year. Mine construction takes 3 years. Output will be increased to the total output in 4 years plus time required by design and obtaining licenses. Mine is planned to operate 37 years at the output level. Number of employees is estimated 600 plus number of personnel of suppliers.

The mine is endangered by water hazard. Dewatering is planned by wells drilled from the surface and established in the hanging wall of the drifts. A detailed hydrogeological exploration is needed before starting mining operations. Quantity of water can be expected $6 \mathrm{~m}^{3} / \mathrm{min}$ according to experiences from Putnok Mine. Water can be utilized in water supply of the region and/or industrial water in chemical industry utilizing coal. Mining operation does not risk drinking water reserves.

The mining area is close to the Lázbérc Protected Area, consequently a complex sensitivity analysis is extremely important. Environmental impact of an underground mine is much less than of a surface operation. Significant part of the inhabitants of the settlements of the region was employed by coal mining so favorable reception of a new mine can be expected.

\section{Surface facilities and infrastructure of the two mines}

Infrastructure required by a new mine is available in the region. There are arterials and main railroad in the valley of Sajó, local roads from the arterial, pipeline of potable water for the supply of the neighboring villages and electric distribution centers.

Former mining facilities do not exist that can be available. So new industrial roads power supply from two independent sources, water supply and sewage and mine water drainage should be built. Furthermore new coal transportation equipment is needed. This will be able to be designed when location and method of the utilization will be known. Proper mine waste disposal site should be established.

New buildings are required by the inclined shafts and the fan furthermore new silos, maintenance facilities, a storage partly covered by shelter, transformers, compressors, boiler, bath, dressing room, lamp house, dispatcher center, office, 
parking place, internal road and railroad network, public utilities and guarding facilities.

\section{Carbon content of the coal}

One of the most important properties of coal as raw material required by coal chemistry is carbon content. The coal reserve of both deposits in question furthermore of all seams throughout the whole basin are relatively young from the Miocene epoch. Consequently its fix (non-organic) carbon content is relatively low and its volatile content is relatively high.

A fairly strict relationship exists between the calorific value and fix carbon content described by a linear regression function as it is shown by Figure 4. A huge number of samples (5648) were analyzed and extremely good correlation (a 0.9845 coefficient of determination and $0.814 \mathrm{MJ} / \mathrm{kg}^{-1}$ mean residual square of estimation) was found.

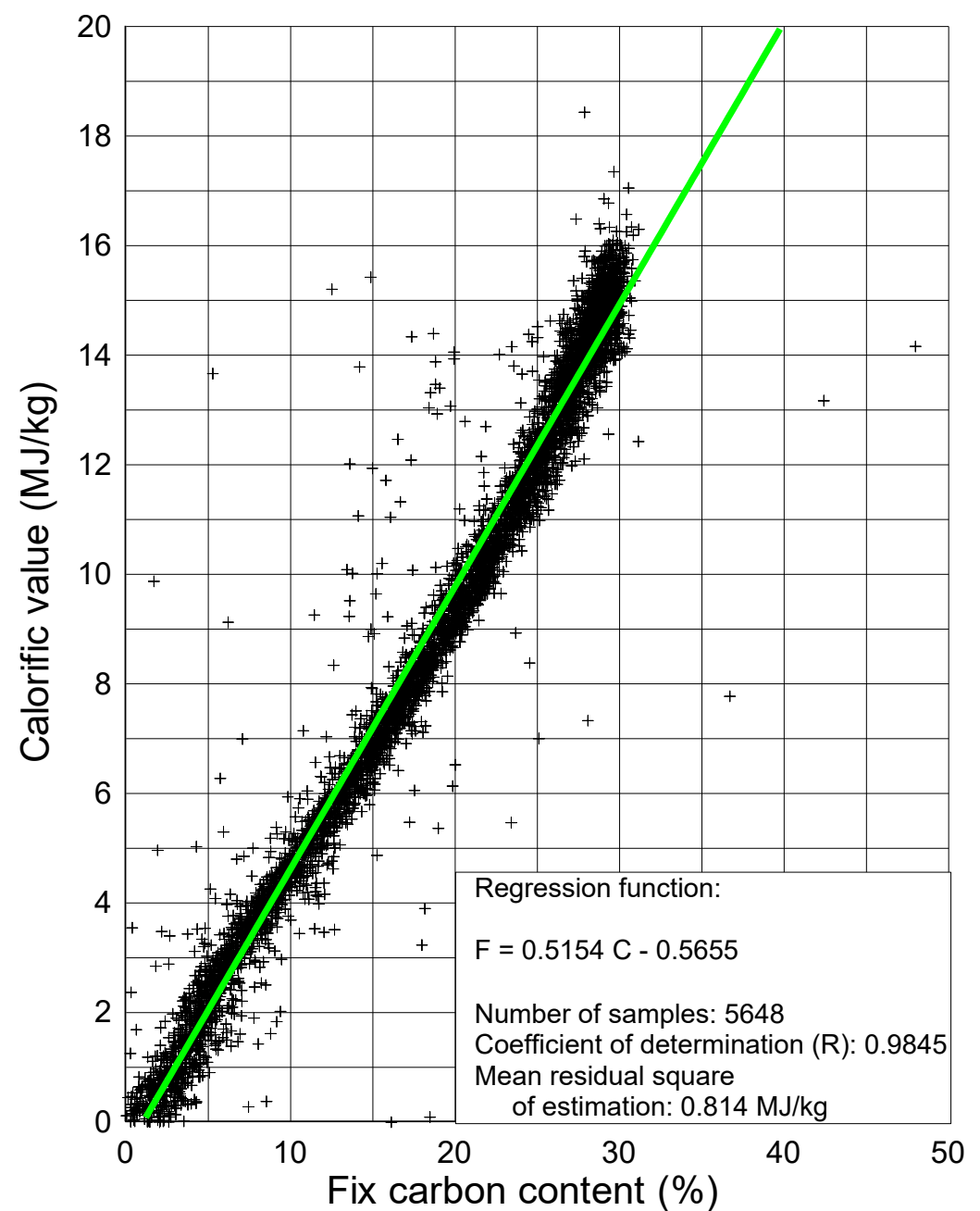

Fig. 4 Calorific value vs. fix carbon content of the coal reserve of the Dubicsány brown coal deposit in the Borsod coal basin in North-Eastern Hungary.

Source: Molnár (editor), 2018

Remaining part of total carbon content of the coal is contained in its volatile part consisting of compounds mostly carbon, hydrogen, nitrogen, oxygen and sulfur. Similarly, confident analysis of 5783 samples was executed resulting linear 
regression of 0.9781 coefficient of determination and $0.978 \mathrm{MJ} / \mathrm{kg}^{-1}$ of mean residual square of estimation. Volatile content is measured approximately 5$35 \%$ of the mass of each samples. Furthermore its combustable elements other than carbon (hydrogen and sulfur) are of relatively smaller quantity and also good linear relationship was found between these quantities and calorific value of coal.

Consequently calorific value can be one of the parameters of the coal seam that can be used for the design of the mining operations.

Unfortunately on the other hand sulfur content of the coal is relatively high than should be taken into account in the selection of the appropriate chemical technology.

\section{D modeling of Seam V of the Dubicsány deposit to enable more accurate estimations for mine design}

A 3D model was and is still being developed to make mining plans more accurate. This model consisted of the following elements.

- Based on the geological data of the deposit a three-dimensional (3D) model was prepared for the numerical computations to determine the quantity and the quality properties of the coal. A picture based on the block model highlights the calorific value of the coal on the upper surface of Seam V (Figure 5). Fine resolution of the model is demonstrated by the sizes of the blocks that are obvious on the figure (Figure 6).

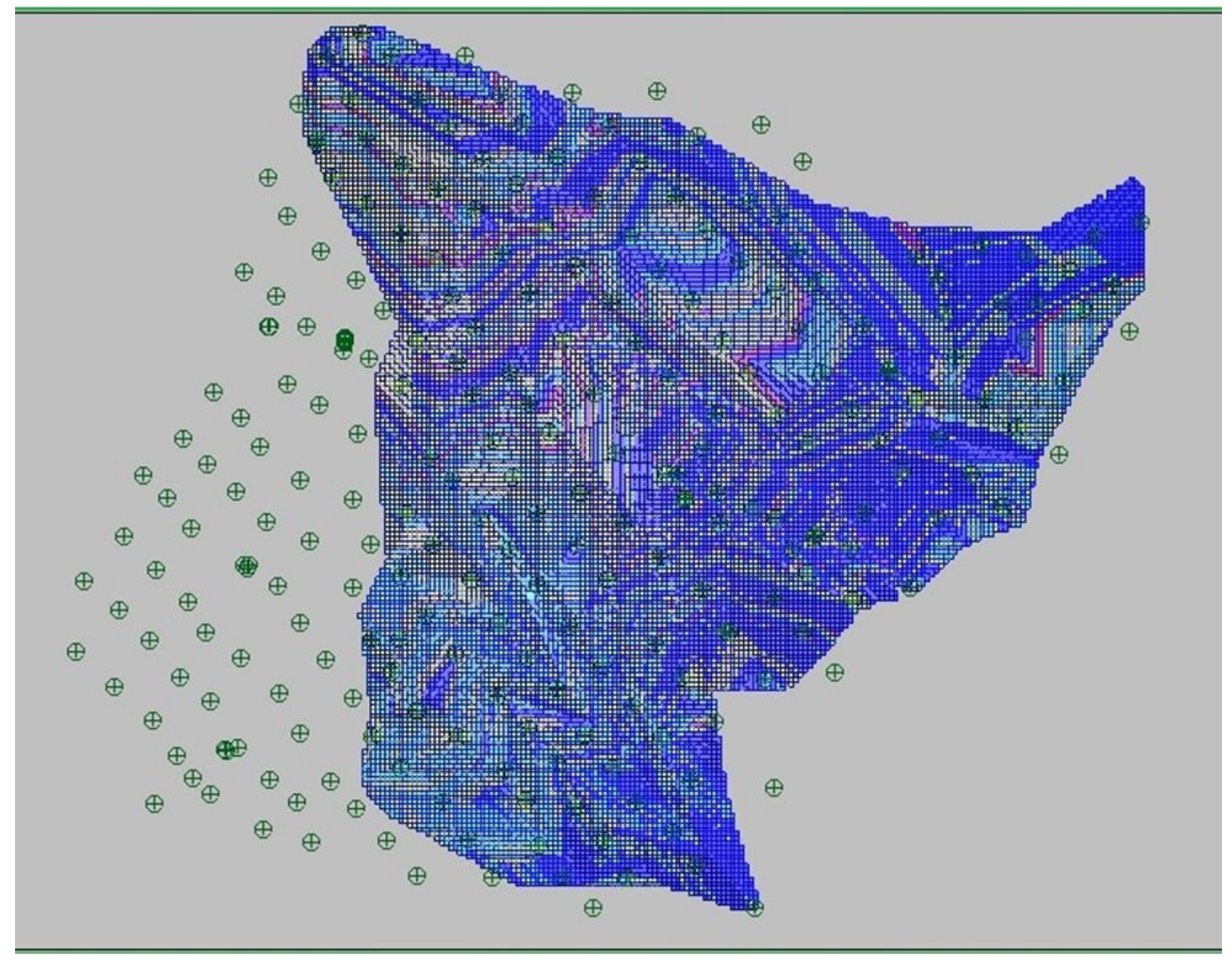

Fig. 5 3D block model of calorific value of Seam V of the Dubicsány deposit Source: Drawn by Tompa R., 2018 


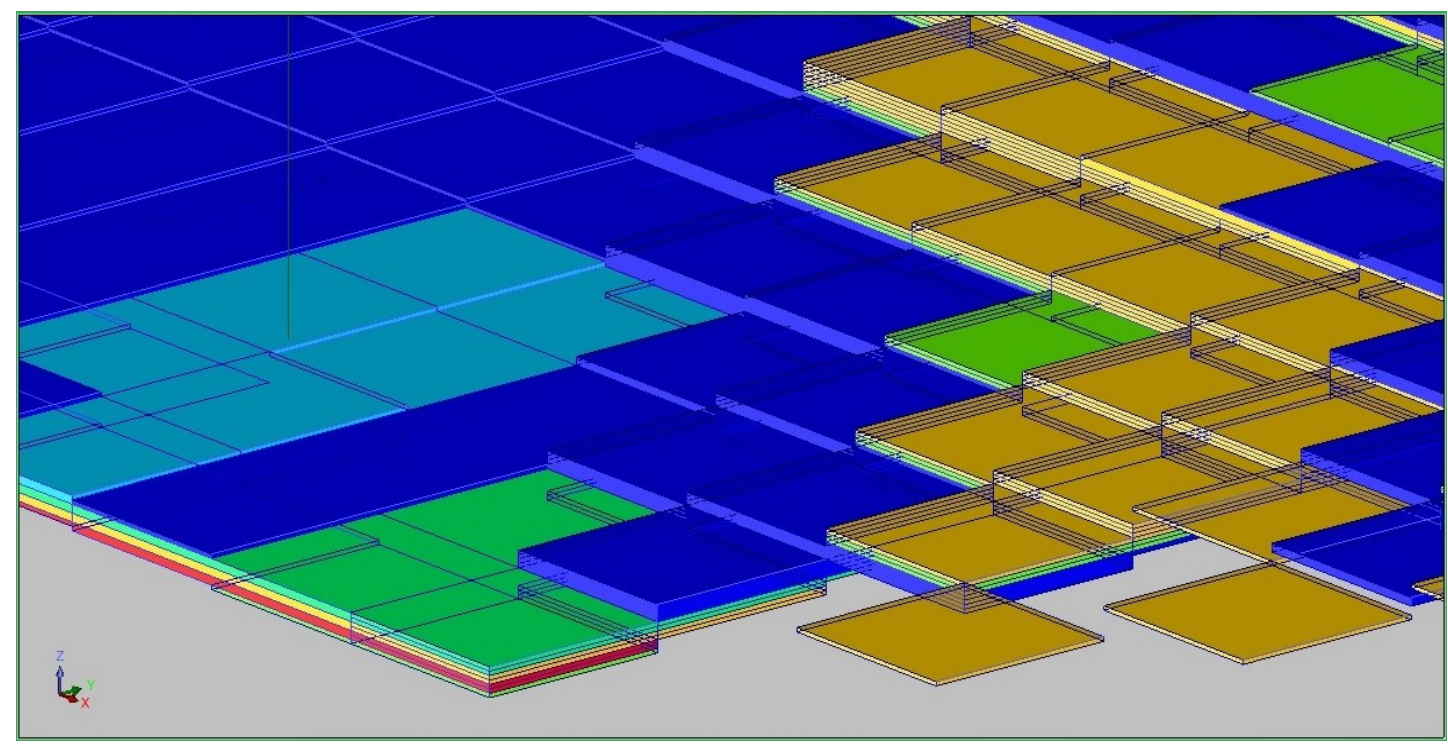

Fig. 6 Ortographic view of a zoomed smaller part of the 3D block model of Seam V of the Dubicsány deposit highlighting its fine resolution

Source: Drawn by Tompa R., 2018

- Calorific value of the coal was determined as a function of different coal quality parameters (moisture, ash, volatile, fix carbon, sulfur, hydrogen content and higher calorific value). Univariate functions were obtained by regression method. Numbers of points used for the estimations were very high (5648-5989). Estimations proved to be accurate as coefficients of determination were fairly high $0.7670<\mathrm{R} 2<0.9948$ and estimated errors of calorific value were low of $0.335 \mathrm{MJ} \cdot \mathrm{kg}^{-1}<\mathrm{D}(\Delta \mathrm{F})<2.248 \mathrm{MJ} \cdot \mathrm{kg}^{-1}$.

- As coal quality changes (deteriorate) obviously from the covering layer of Seam V downwards, it is an extremely important question to determine the proper height of the coal face of the longwalls. This is important for the correct selection of the longwall equipment thus enabling selective cutting. A numerical analysis was done to find the distribution functions of the mass and the heat content furthermore the mean calorific value of the coal as a function of coal face height for the four parts of the mine. Future owners will be able to use these result for proper decisions in mine valuation and mining engineering design.

\section{ACKNOWLEDGEMENTS}

The described work/article was carried out as part of the "Sustainable Raw Material Management Thematic Network - RING 2017”, EFOP-3.6.2-16-201700010 project in the framework of the Széchenyi 2020 Program. The realization of this project is supported by the European Union, co-financed by the European Social Fund.

\section{REFERENCES}

Darling, P. editor (2011), SME Mining Engineering Handbook. Society of the Mining, Metallurgical and Mineral Exploration Inc. (SME, U.S.)

Debreczeni, Á., Havelda, T., Bombicz, J., Kaufmann, T., Verbőci, J., Bariczkayné Szeiler, Z. (2018), Kiemelt mélymüvelésű szénbányászati projektek földtani bányászati adottságai. In Püspöki Z. (editor-in-chief), A hazai szénvagyon és 
hasznosítási lehetöségei. Magyar Bányászati és Földtani Szolgálat, Budapest, pp. 85-146.

Molnár J. editor (2018), A dubicsányi barnakőszén előfordulás geometriai és minőségi adottságainak háromdimenziós modellezése, a gazdaságosan kitermelhető vagyon mennyiségének és minőségének újraértékelése. Kutatási jelentés. Miskolci Egyetem, Bányászai és Geotechnikai Intézet, Miskolc

Molnár, J., Tompa, R. (2016), Some questions of mine safety of small mines in Hungary. In $7^{\text {th }}$ International Multidisciplinary Scientific Symposium - Universitaria SIMPRO 2016, 14-15 October,2016, Petrosany, pp. 445-450. Available at https://www.upet.ro/simpro/2016/downloads/Proceedings\%20SIMPRO\%202016 .pdf. (Accessed: August $27^{\text {th }}, 2018$ )

Molnár, J., Debreczeni, Á., Tompa, R. (2018), Challenges and Opportunities of Underground Coal Mining in North-Eastern Hungary. In Proc. $8^{\text {th }}$ International Multidisciplinary Symposium "Challenges and opportunities for sustainable development through quality and innovation in engineering and research management", UNIVERSITARIA SIMPRO 2018, pp347-352.. Available at https://www.upet.ro/simpro/2018/downloads/Proceedings\%20SIMPRO\%202018 .pdf. (Accessed May 23, 2019)

Püspöki Z. editor-in-chief (2018), A hazai szénvagyon és hasznosítási lehetőségei. Magyar Bányászati és Földtani Szolgálat, Budapest.

\begin{abstract}
.
Numerous underground coal mines were in operation in the Borsod coal basin in northeastern part of Hungary until the beginning of this century. The main area of utilization of the mined out coal beside power and heat generation was supplying households with fuel mostly for heating. In the beginning of the 1990ies the power plants in question were shut down for economic, environmental and technical reasons. Consequently all the mines were closed no later than 2004 and thousands of miners lost their jobs. A new perspective of coal mining can be enabled by other ways of utilization of coal, e.g. coal chemistry, etc. Safe and modern equipment and technology enabling high output, clean coal, furthermore high rate of yield are targeted. Opportunity of sustainable underground coal mining in the north-eastern part of Hungary is discussed in the paper. Analysis of the properties of coal deposits using threedimensional (3D) modelling are used for considering opportunities of new mining operations. Models are being developed.
\end{abstract}

Keywords: underground mining; sustainability; clean coal; coal 